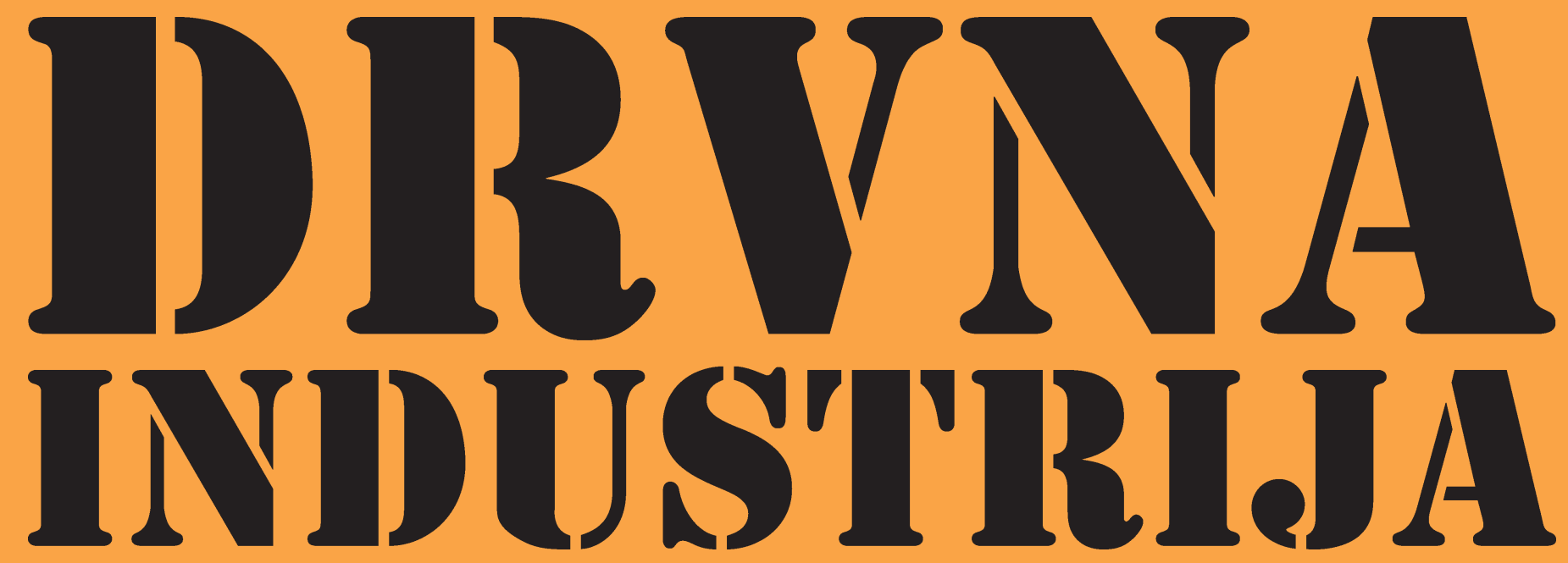

ZNANSTVENI ČASOPIS ZA PITANJA DRVNE TEHNOLOGIJE • ZAGREB • VOLUMEN $65 \cdot$ BROJ 2 SCIENTIFIC JOURNAL OF WOOD TECHNOLOGY・ZAGREB・VOLUME $65 \cdot N U M B E R 2$ 
....... Čufar, Šefc, De Luis, Morgós, Grabner, Merela, Trajković: Tree-Ring Chronology ...

Katarina Čufar ${ }^{1}$, Bogoslav Šefc ${ }^{2}$, Martin De Luis ${ }^{3}$, András Morgós ${ }^{4}$, Michael Grabner ${ }^{5}$, Maks Merela ${ }^{1}$, Jelena Trajković ${ }^{2}$

\title{
Tree-Ring Chronology of Pedunculate Oak (Quercus robur) and its Potential for Development of Dendrochronological Research in Croatia
}

\section{Kronologija godova hrasta lužnjaka (Quercus robur) i njezin potencijal za razvoj dendrokronoloških istraživanja u Hrvatskoj}

\author{
Original scientific paper • Izvorni znanstveni rad \\ Received-prispjelo: 9. 7. 2013. \\ Accepted-prihvaćeno: 9. 4. 2014. \\ UDK: $630 * 811.4 ; 674.031 .632 .26$ \\ doi:10.5552/drind.2014.1337
}

\begin{abstract}
We present the local tree-ring chronology of pedunculate oak (Qercus robur) from Kobiljak near

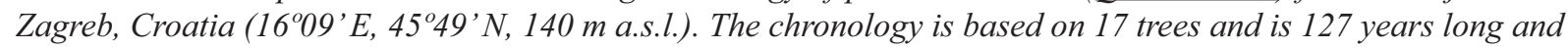
covers the period of 1883-2009. The well replicated part of the residual version of the ARSTAN chronology with SSS $>0.80$ (interval of 88 years, period 1922-2009) was used for dendroclimatological analysis, which showed that June precipitation has positive and temperature has negative effect on tree-ring variation. Comparison with 40 available oak chronologies from the surrounding countries confirmed its good teleconnection with 2 local oak chronologies from Austria, 2 from Hungary, and 3 from Slovenia. It also exhibits good heteroconnection, i.e. similarity with chronologies of beech (Fagus sylvatica), from various sites in Slovenia. The similarities can be ascribed to response to common climatic factors. The results indicate that the chronology could be a good reference point for constructing a longer regional chronology in Croatia and surrounding countries, which could be used for different purposes including dating of objects of cultural heritage.
\end{abstract}

Keywords: dendrochronology, pedunculate oak (Quercus robur), dendroclimatology, teleconnection, heteroconnection

\footnotetext{
Authors are professor and assistant professor at University of Ljubljana, Biotechnical Faculty, Department of Wood Science and Technology, Ljubljana, Slovenia. ${ }^{2}$ Authors are assistant professor and professor at University of Zagreb, Faculty of Forestry, Department for Wood Science, Zagreb, Croatia. ${ }^{3}$ Author is professor at University of Zaragoza, Department of Geography and Regional Planing, Zaragoza, Spain. ${ }^{4}$ Author is professor at Korea National University of Cultural Heritage, Buyeo, Korea. ${ }^{5}$ Author is researcher at University of Natural Resources and Life Sciences, Vienna, Institute of Wood Technology and Renewable Resources, Tulln, Austria.

Autori su profesorica i docent Sveučilišta u Ljubljani, Biotehnički fakultet, Odsjek za znanost o drvu i drvnu tehnologiju, Ljubljana, Slovenija. ${ }^{2}$ Autori su docent i profesorica Sveučilišta u Zagrebu, Šumarski fakultet, Drvnotehnološki odsjek, Zagreb, Hrvatska. ${ }^{3}$ Autor je profesor Sveučilišta u Zaragozi, Odsjek za geografiju i regionalno planiranje, Zaragoza, Španjolska. ${ }^{4}$ Autor je profesor Korejskoga nacionalnog sveučilišta kulturne baštine, Buyeo, Koreja. ${ }^{5}$ Autor je istraživač Sveučilišta prirodnih resursa i bioloških znanosti, Beč i Instituta drvne tehnologije i obnovljivih izvora, Tulln, Austria.
} 
SAŽETAK • U radu je predstavljena lokalna kronologija godova hrasta lužnjaka (Qercus robur) iz Kobiljaka

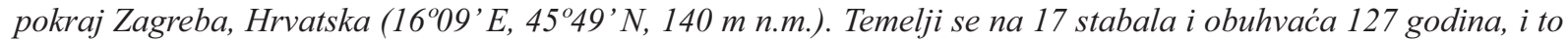
razdoblje od 1883. do 2009. Za dendroklimatološku analizu primijenjen je optimalan replicirani dio rezidualne inačice kronologije ARSTAN sa SSS>0,80 (dužina 88 godine, razdoblje 1922. - 2009.). Analiza je pokazala pozitivan učinak lipanjskih oborina na promjene širine godova, dok je učinak temperature u istome mjesecu negativan. Usporedba s 40 dostupnih hrastovih kronologija iz okolnih zemalja potvrdila je telekonekciju $s$ dvije lokalne kronologije hrasta iz Austrije, dvije iz Mađarske i tri iz Slovenije. Ona također pokazuje dobru heterokonekciju, tj. sličnost s kronologijama bukve (Fagus sylvatica) s različitih staništa u Sloveniji. Sličnosti se mogu pripisati odgovoru na zajedničke klimatske čimbenike. Rezultati upućuju na zaključak da ta kronologija može biti dobro polazište za izradu dulje regionalne kronologije hrasta u Hrvatskoj i susjednim državama, koja bi onda mogla imati različite namjene, uključivši i datiranje objekata kulturne baštine.

Ključne riječi: dendrokronologija, hrast lužnjak (Quercus robur), dendroklimatologija, telekonekcija, heterokonekcija

\section{INTRODUCTION} 1. UVOD

Numerous wood science laboratories in the world develop dendrochronology, which as a rule includes investigations of tree ring widths and wood structure. Oak (Quercus sp.) is considered the most important wood in European dendrochronology. It is mainly represented by the pedunculate oak (Quercus robur L.) and sessile oak (Q. petraea Liebl.), which cannot be differentiated by their wood anatomy. Despite different ecological requirements of the two species, their treering patterns usually show good agreement. Therefore, they are often treated together as European oak or simply oak (Quercus sp.).

Since the 1990s, when the construction of the first multimillennial oak chronologies was completed (Baillie, 1995), oak dendrochronology has made considerable progress. The longest tree-ring chronology in the world is the oak chronology of the laboratory in Hohenheim reaching back to 8480 BC (Friedrich et al., 2004). There are several other millennial chronologies, which have been constructed all over the western and central Europe (e.g., for review see Haneca et al., 2009). Oak research has been at the same time extended also to areas, which were for a long time considered as less optimal for dendrochronology, like Flanders/ Belgium (Haneca et al., 2006). It has also been extended to the areas east, and southeast of traditional oak research (e.g. Wimmer and Grabner, 1998; Gryaneus, 1996, 2003; Geihofer et al., 2005; Morgos, 2005; Pukiene and Ožalas, 2007; Szántó et al., 2007; Čufar et al., 2008a, 2010: Kern et al., 2009a, b; Grabner et al., 2011; Kolar et al., 2012).

Long tree-ring chronologies have been used for investigating the past and for predicting future changes in the climate and environment (e.g. Friedrichs et al., 2009a, b; Kern et al., 2009; Haupt et al. 2011; Levanič et al., 2011). In addition, they were used for dating of archaeological wood and artefacts from historic constructions and archaeological sites (e.g., for review see Čufar, 2007; Haneca et al., 2009).

In Slovenia, a neighbouring country of Croatia, which has similar climate regimes to some extent (Alpine, Mediterranean and continental), the first local tree ring chronologies of oak were constructed in the 1990s (Čufar and Levanič, 1999), but their tree-ring patterns seemed to have no similarity with oak chronologies from other countries, such as those north of the Alps. Recently, a 548 years long regional oak chronology has been constructed in SE Slovenia, showing a good supra-regional signal reflected in the radius of ca. $500 \mathrm{~km}$, which demonstrated to be climatic in its nature (Čufar et al., 2008a). It enabled reconstruction of climate for the span of the chronology, indicating that hot and dry June conditions limit the growth of oak in the area (Čufar et al., 2008b). Reconstructed years with extremely hot-dry and wet-cool conditions could be confirmed by the reports in archived documents. Interestingly, the extreme years did not agree with those reconstructed from oak tree-rings in Western Europe (Kelly et al., 2002). The Slovenian oak chronology, which showed good teleconnection with the chronologies of the surrounding countries, has also been successfully used for dating the wood of the objects in Slovenia as well as the objects of the Croatian cultural heritage (Čufar and Šimek, 2008; Čufar et al., 2006, 2008c).

Since the tree-ring chronologies can be considered 'living organisms', it is necessary to work to improve and prolong the existing ones and to construct the new ones, especially in Croatia and neighboring countries where dendrochronological research still needs to be developed.

The objectives of this study are (1) to construct a local oak chronology for the site near Zagreb, Croatia, (2) to show how climatic factors influence tree-ring variation of oak in the sampling area, (3) to find out if there exists teleconnection of this chronology with oak chronologies in the surrounding countries (4) and if there exists heteroconnection of Croatian oak with other tree species. All of this would provide useful information to develop a strategy to improve dendrochronological research in Croatia.

\section{MATERIAL AND METHODS} 2. MATERIJAL I METODE

\subsection{Study Area and Wood for Tree-Ring Research} 2.1. Područje i drvo obuhvaćeno istraživanjem

The sampling area Kobiljak (16 $09^{\circ}$ E, $45^{\circ} 49^{\prime} \mathrm{N}$, $140 \mathrm{~m}$ a.s.1.) is located $20 \mathrm{~km}$ east of Zagreb. The sampling trees originated from the forest association Genisto elatae-Quercetum roboris Ht. 1938 composed of pedun- 
....... Čufar, Šefc, De Luis, Morgós, Grabner, Merela, Trajković: Tree-Ring Chronology ...

culate oak (Quercus robur L.) mixed with big greenweed on the area where the level of ground water is high. The age of trees was estimated to $140-150$ years.

\subsection{Dendrochronological analysis}

\subsection{Dendrokronološka analiza}

For dendrochronological investigations, disks from 17 felled Quercus robur trees (DBH $40 \pm 5 \mathrm{~cm}$ ) were taken at $4 \mathrm{~m}$ above ground. The wood was polished and tree-ring widths were measured along the mean diameter, i.e. two radii, to the nearest $0.01 \mathrm{~mm}$ using TSAP-Win program (Frank Rinn, Heidelberg, Germany). The tree-ring series were visually and statistically crossdated and compared with each other by calculating the $t$-values according to Baillie and Pilcher (1973) and coefficient of agreement (Gleichläufigkeit - Glk) (Eckstein and Bauch 1969) using TSAPWin program. Tree-ring series, two per each tree, were crossdated, and series of 33 radii were found acceptable for further analyses.

Crossdated tree-ring series of individual trees were assembled into a chronology using the program ARSTAN (Holmes 1994). We calculated ARSTAN chronologies, a non-detrended - raw-data, and a detrended residual chronology.

\subsection{Tree rings and climate}

\subsection{Godovi i klima}

The climatic influence on tree growth was studied using the residual version of the ARSTAN chronology (expressed as tree-ring indexes vs. time), for which the original tree-ring width series were standardized in a two-step procedure. First, the long-term trend was removed by fitting a negative exponential function (regression line) to each tree-ring series. Second, a more flexible detrending was made by a cubic smoothing spline with a $50 \%$ frequency response of 30 years to further reduce non-climatic variance. Subsequently, autoregressive modelling of the residuals and biweight robust estimation of the mean were applied (Cook and Peters, 1997).

The climatic data (average monthly temperatures and monthly sums of precipitation for the period 1922 to 2009) were obtained from the meteorological station Grič, Zagreb (Figure 1). The station is representative for the sampling area.

The climate/growth relationships were calculated using the program DendroClim2002 (Biondi and Waikul 2004), whereby the residual version of the tree-ring chronology was the dependent variable and the regressors were the monthly mean temperatures and monthly sums of precipitation for each biological year from the previous October to the current September over the time axis from 1922 to 2009. DendroClim2002 uses correlation functions and response functions, which are the most common statistical models used in dendrochronology. The term 'function' indicates a sequence of coefficients computed between the tree-ring chronology and monthly climatic variables, which are ordered in time from the previous-year growing season to the current one. In 'correlation' functions, the coefficients are univariate estimates of Pearson's product

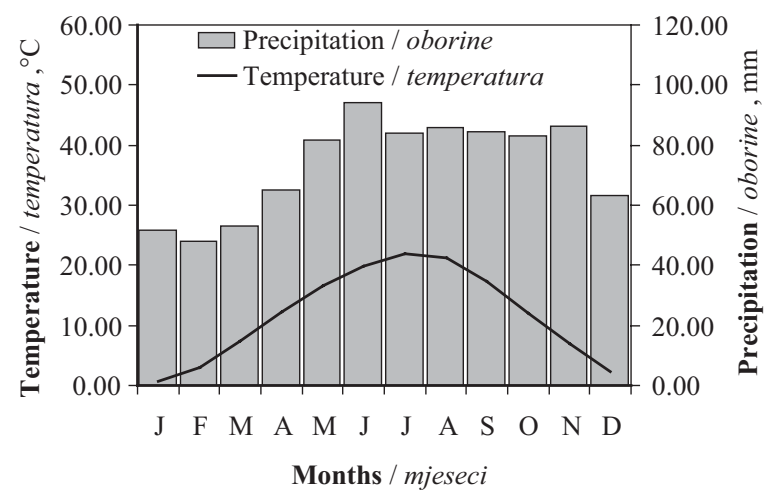

Figure 1 Bagnouls Gaussen Climatic Diagram, mean monthly average temperature (line) and mean monthly sum of precipitation (bars), of meteorological station Grič, Zagreb for the period 1922-2009; the mean annual precipitation is $879 \mathrm{~mm}$ and the mean annual temperature is $11.76{ }^{\circ} \mathrm{C}$

Slika 1. Dijagram klime, prosječne mjesečne temperature (linija) i prosječnog zbroja mjesečnih oborina (stupići) u meteorološkoj postaji Grič, Zagreb, za razdoblje 1922. 2009.; prosjek godišnjih oborina iznosi $879 \mathrm{~mm}$, a prosjek godišnje temperature $11,76^{\circ} \mathrm{C}$

moment correlation, while in 'response' functions, the coefficients are multivariate estimates from a principal component regression model (Biondi and Waikul, 2004). The program applies a bootstrap process according to Guiot (1991) to assess the statistical significance of the correlation and response function.

The stability in time of the climate/growth relationships was checked by moving the correlation and response function, calculated for a 60 -year time window, over the chronological life span from 1883 to 2009 (Biondi 1997).

\subsection{Teleconnection and heteroconnection 2.4. Telekonekcija i heterokonekcija}

The residual oak chronology of Kobiljak was tested for teleconnection. It was compared with oak chronologies from Austria, Hungary, Slovenia and Serbia (Čufar et al., 2014). For this purpose, we prepared residual chronologies of 40 sites (27 from Austria, 9 from Hungary, 3 from Slovenia and 1 from Serbia) according to the same procedure described above.

In addition, we also tested the residual oak chronology of Kobiljak with 15 available tree-ring chronologies of beech (Fagus sylvatica L.) (Čufar et al. 2008d) prepared according to the same procedure.

Comparison of the chronology of Kobiljak and others was made by calculating the $t$-values and coefficients of agreement (Gleichläufigkeit - Glk) using TSAP-Win.

\section{RESULTS AND DISCUSSION 3. REZULTATI I RASPRAVA}

\subsection{Chronology}

3.1. Kronologija

The obtained oak chronology of Kobiljak (abbreviation HR1) is based on tree-ring data from 17 trees (33 radii). It is 127 years long and covers the period 1883-2009 (Figure 2), however its optimally replicated 

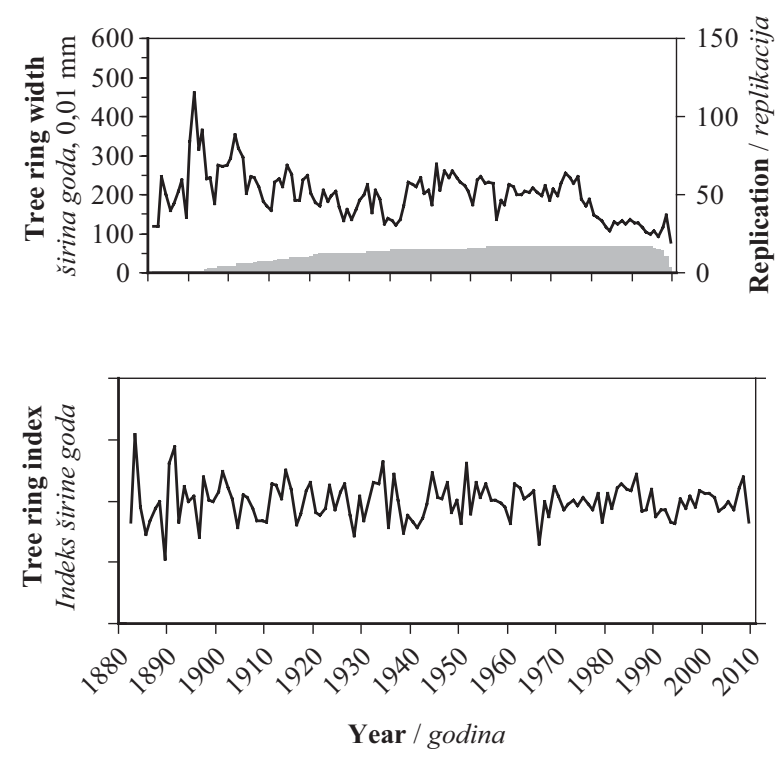

Figure 2 Oak tree-ring chronology of Kobiljak near Zagreb (HR1): raw-data chronology with replication (above) and detrended residual chronology (below); the optimally replicated part of the chronology extends from 1922 to 2008 and is 88 years long. It is based on 17 trees with subsample signal strength $(\mathrm{SSS})>0.80$

Slika 2. Kronologija godova hrasta iz Kobiljaka pokraj Zagreba (HR1): kronologija nestandardiziranih širina godova s replikacijom (iznad) i rezidualna kronologija (ispod); optimalno replicirani dio kronologije proteže se od 1922. do 2008. i dug je 88 godina, temelji se na 17 stabala sa signalom jakosti poduzorka $(\mathrm{SSS})>0,80$

Table 1 Descriptive statistics of Kobiljak near Zagreb (HR1) oak chronology, period 1922-2009, based on 17 trees Tablica 1. Opisna statistika kronologije hrasta iz Kobiljaka pokraj Zagreba (HR1), razdoblje 1922. -2009., utemeljene na 17 stabala

\begin{tabular}{|l|c|c|}
\hline \multicolumn{1}{|c|}{$\begin{array}{c}\text { Chronology type } \\
\text { Tip kronologije }\end{array}$} & $\begin{array}{c}\text { Raw } \\
\text { Neobradeno }\end{array}$ & $\begin{array}{c}\text { Residual } \\
\text { Rezidual }\end{array}$ \\
\hline $\begin{array}{l}\text { Mean, mm } \\
\text { Prosjek, mm }\end{array}$ & 2.0055 & 0.9975 \\
\hline $\begin{array}{l}\text { Median, mm } \\
\text { Median, mm }\end{array}$ & 2.0270 & 1.0038 \\
\hline $\begin{array}{l}\text { Mean sensitivity } \\
\text { Srednja osjetljivost }\end{array}$ & 0.1561 & 0.1655 \\
\hline $\begin{array}{l}\text { Standard deviation, mm } \\
\text { Standardna devijacija, mm }\end{array}$ & 0.6070 & 0.1540 \\
\hline $\begin{array}{l}\text { Autocorrelation order 1 } \\
\text { Autokorelacijski red 1 }\end{array}$ & 0.6959 & -0.0508 \\
\hline $\begin{array}{l}\text { Autocorrelation order 2 } \\
\text { Autokorelacijski red 2 }\end{array}$ & 0.1672 & -0.0602 \\
\hline $\begin{array}{l}\text { Autocorrelation order 3 } \\
\text { Autokorelacijski red 3 }\end{array}$ & 0.0686 & 0.0079 \\
\hline $\begin{array}{l}\text { Mean correlation between trees } \\
\text { Prosječna korelacija između } \\
\text { stabala }\end{array}$ & 0.220 & 0.241 \\
\hline $\begin{array}{l}\text { Signal-to-noise ratio } \\
\text { Omjer signal-šm }\end{array}$ & 3.360 & 4.118 \\
\hline $\begin{array}{l}\text { Variance in first eigenvector, \% } \\
\text { Varijanca prvog svojstvenog } \\
\text { vektora, \% }\end{array}$ & $32.92 \%$ & $30.44 \%$ \\
\hline
\end{tabular}

part, based on 13 or more trees, extends from 1922 to 2009 and reaches the subsample signal strength (SSS) $>0.80$. The statistics of the raw-data and residual chronologies HR1 is given in Table 1 .

\subsection{Climatic signal in chronology}

3.2. Klimatski signal u kronologiji

Below-average temperature and above-average precipitation in June, i.e. a cool and moist June, are the most significant factors favoring oak growth on the site (Fig. 3). The correlation (r) between the residual treering chronology and June precipitation is 0.333 , while the correlation with June temperature series is -0.325 .

In addition, both precipitation and especially temperature showed a consistent stability over a period of about 60 years (Fig. 4).

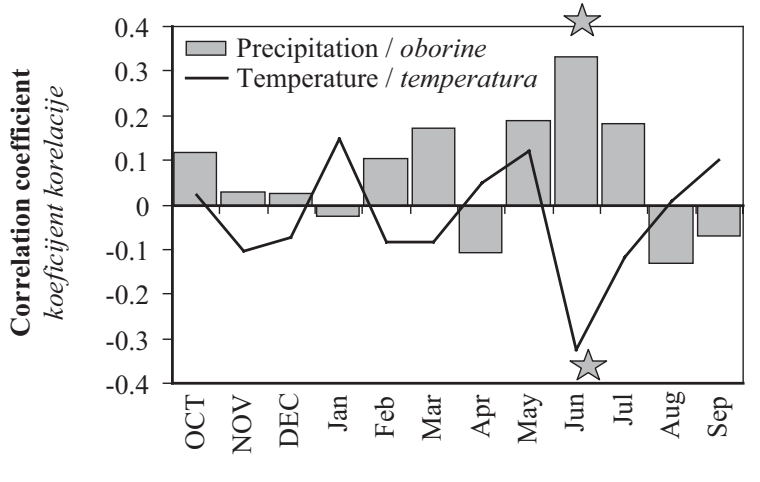

(a)

Months / mjeseci

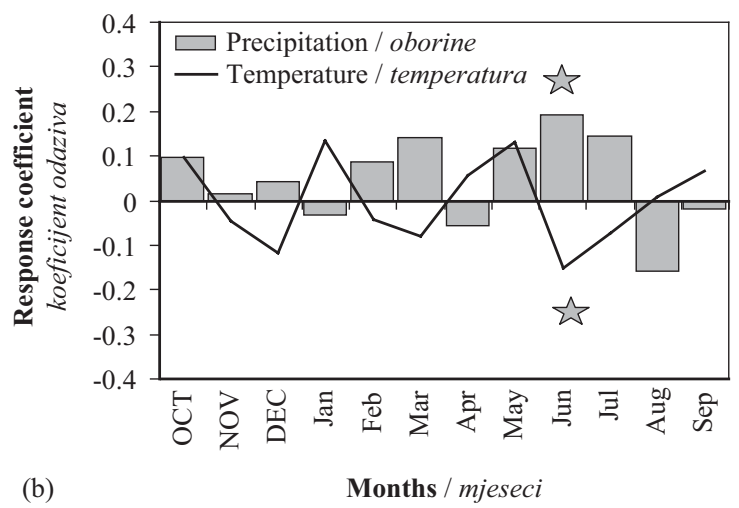

Figure 3 Correlation (a) and response coefficients (b) calculated between the residual version of oak chronology of Kobiljak near Zagreb (HR1) and monthly temperature (line) and precipitation (bars) from previous October to current September for the period 1922-2009; stars indicate significance at $95 \%$ level

Slika 3. Koeficijenti korelacije (a) i odaziva (b) izračunani iz rezidualne kronologije hrasta iz Kobiljaka pokraj Zagreba (HR1) te mjesečnih temperatura (crta) i oborina (stupići) između prethodnog listopada i tekućeg rujna za razdoblje 1922. - 2009.; zvjezdice upućuju na značajnost pri razini vjerojatnosti od $95 \%$

\subsection{Teleconnection \\ 3.3. Telekonekcija}

The results of teleconnection of the HR1 chronology with the chronologies from Austria, Hungary, Slovenia and Serbia is given in Table 2. Although the comparison of HR1 was made with 40 residual chronologies prepared according to the same standardiza- 


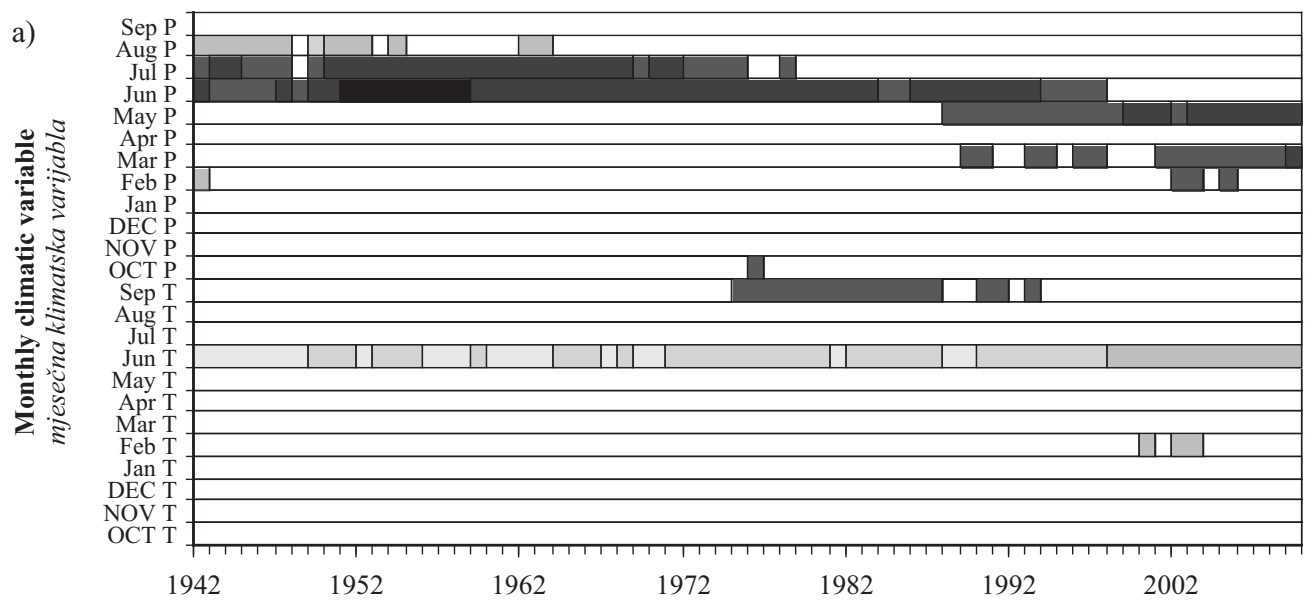

Last year of interval / zadnja godina intervala

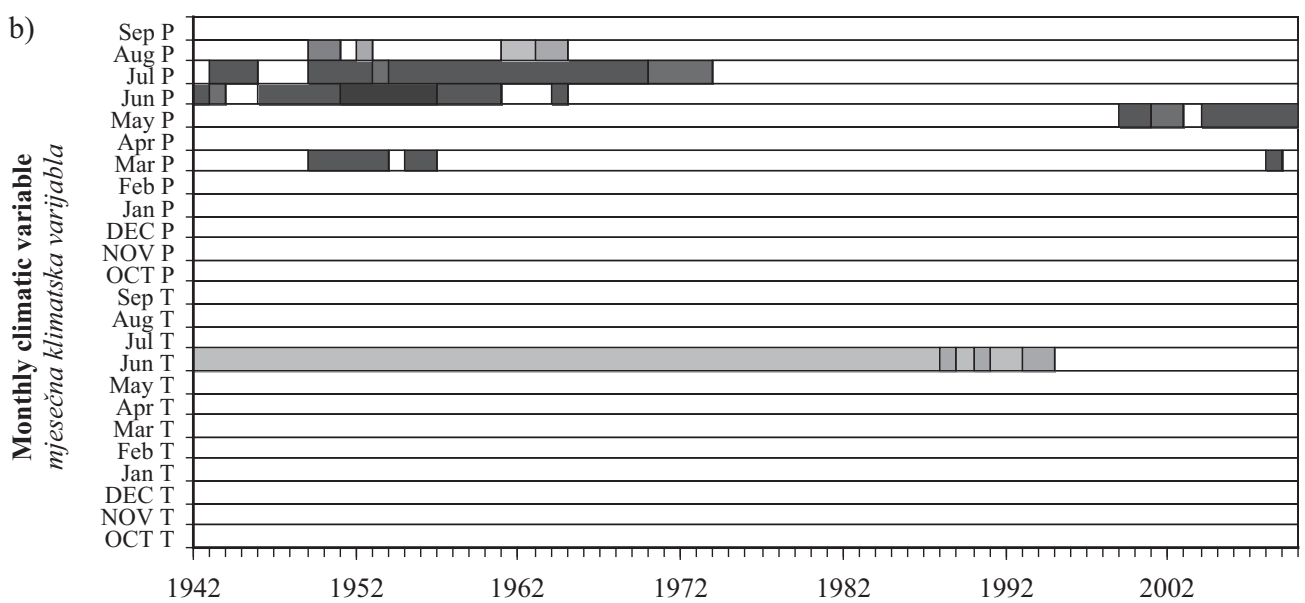

Last year of interval / zadnja godina intervala

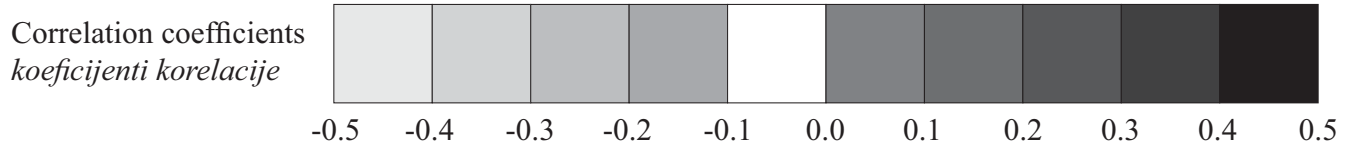

Figure 4 Moving correlation values (a) and response values (b), computed with DendroCLIM2002 (interval of 60 years); the first interval is from 1922 to 1981 and the last from 1950 to 2009; months written in capitals mean months of the previous year (i.e. DEC). Only significant values are shown.

Slika 4. Pomične korelacijske vrijednosti (a) i vrijednosti odaziva (b) (duljina intervala 60 godina); prvi se interval proteže od 1922. do 1981., a zadnji od 1950. do 2009.; mjeseci pisani velikim slovima znače mjesece prethodne godine (npr. DEC) .

Prikazane su samo značajne vrijednosti.

Table 2 Crossdating parameters for comparison of the residual chronology of oak from Kobiljak near Zagreb, Croatia (HR1) with local residual oak chronologies from Austria (A*), Hungary (U*), Slovenia (SI*); for the locations, compare Fig. 5 (parameters: overlapping - Ovl, coefficient of agreement $-\mathrm{Glk} \%$ and t-value $-t_{\mathrm{BP}}$ )

Tablica 2. Parametri za usporedbu rezidualne kronologije hrasta iz Kobiljaka pokraj Zagreba, Hrvatska (HR1) s lokalnim rezidualnim kronologijama hrasta iz Austrije (A*), Mađarske (U*), Slovenije (SI*); lokacije usporediti sa slikom 5. (Ovl preklapanje, Glk - koeficijent slaganja, $\mathrm{t}_{\mathrm{BP}}-t$ vrijednost)

\begin{tabular}{|c|c|c|c|c|c|c|c|c|}
\hline \multicolumn{9}{|c|}{$\begin{array}{l}\text { Comparison with oak chronology HR1, period 1922-2008, Longitude16 }{ }^{\circ} \mathbf{0 9} \text { ' E, Latitude } \mathbf{4 5}^{\circ} \mathbf{4 9} \text { ' N, Altitude } 140 \text { m a.s.l. } \\
\text { Usporedba sa kronologijom hrasta HR1, razdoblje 1922. - 2008., zemljopisna dužina } 16^{\circ} 09 \text { E, zemljopisna širina } 45^{\circ} 49^{\prime} \mathrm{N} \text {, } \\
\text { visina } 140 \text { m n.m. }\end{array}$} \\
\hline \begin{tabular}{|l|} 
Code \\
Oznaka \\
\end{tabular} & Ovl & $\mathrm{t}_{\mathrm{BP}}$ & Glk (\%) & \begin{tabular}{|l} 
Location \\
Mjesto
\end{tabular} & \begin{tabular}{|l|} 
Country \\
Zemlja
\end{tabular} & $\begin{array}{l}\text { Longitude } \\
\text { Dužina }\end{array}$ & $\begin{array}{l}\text { Latitude } \\
\text { Širina }\end{array}$ & $\begin{array}{l}\text { Altitude (m a.s.l.) } \\
\text { Visina }(m \text { n.m })\end{array}$ \\
\hline U02 & 80 & 6.6 & 70.9 & Zamárdi & Hungary & $17.90^{\circ}$ & $46.83^{\circ}$ & 204 \\
\hline SI1 & 82 & 6.0 & 77.8 & Novo mesto & Slovenia & $15.18^{\circ}$ & $45.80^{\circ}$ & 220 \\
\hline SI2 & 82 & 5.1 & 75.9 & Celje-Kozjansko & Slovenia & $15.25^{\circ}$ & $46.25^{\circ}$ & 240 \\
\hline SI3 & 75 & 4.8 & 73.0 & Ljubljana & Slovenia & $14.48^{\circ}$ & $46.07^{\circ}$ & 299 \\
\hline U06 & 80 & 4.8 & 64.6 & Bürüs & Hungary & $17.77^{\circ}$ & $45.97^{\circ}$ & 120 \\
\hline A04 & 86 & 4.3 & 64.7 & Fehring & Austria & $16.02^{\circ}$ & $46.93^{\circ}$ & 270 \\
\hline A14 & 87 & 4.2 & 69.8 & Baumgarten an der March & Austria & $16.53^{\circ}$ & $48.31^{\circ}$ & 145 \\
\hline
\end{tabular}




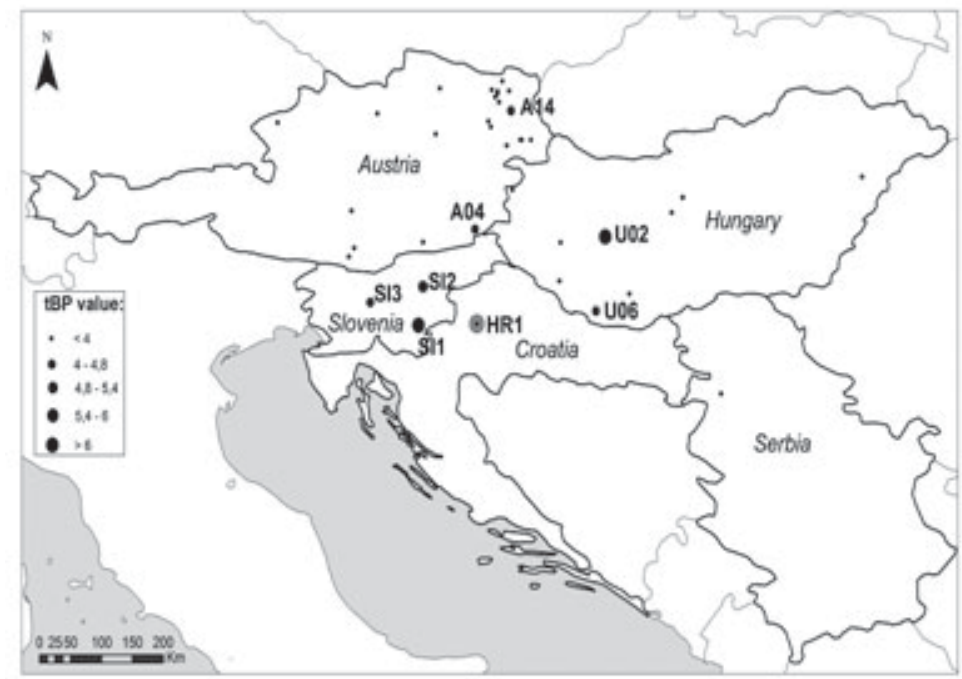

Figure 5 Teleconnection of Kobiljak near Zagreb oak chronology (HR1) with local oak chronologies from Austria, Hungary, Slovenia and Serbia; the chronologies showing $t_{\mathrm{BP}} \geq 4$ are indicated with progressively large points and labels, small points without label represent chronologies with $t_{\mathrm{BP}}<4$; for details of teleconnection see Table 2

Slika 5. Telekonekcija kronologije hrasta iz Kobiljaka blizu Zagreba (HR1) s lokalnim kronologijama hrasta iz Austrije, Mađarske, Slovenije i Srbije. Kronologije koje pokazuju $t_{\mathrm{BP}} \geq 4$ naznačene su oznakom i postupno većim točkama, a male točke bez oznake predočuju kronologije $\mathrm{s} t_{\mathrm{BP}}<4$; statistički parametri telekonekcije navedeni su u tablici 2.

tion procedure, we list only the statistically significant agreements with $t_{\mathrm{BP}} \geq 4$.

Out of 40 chronologies used for comparison, 7 showed significant similarity $\left(t_{\mathrm{BP}} \geq 4\right)$ with HR1 chronology in its well replicated part (1922-2009). The chronologies showing similarity are located NE, N and NW from Kobiljak. The most distant chronology A14 is from Baumgarten in Austria ca. $270 \mathrm{~km}$ away (as a crow flies), and the nearest one is SI1 from the area of Novo mesto in Slovenia ca. $60 \mathrm{~km}$ away. The highest agreement $\left(t_{\mathrm{BP}}=6.7\right)$ was obtained with the U02 chronology of Zamárdi in Hungary, which is ca. $230 \mathrm{~km}$ away from Kobiljak. The values of coefficients of agreement were in all cases above $64 \%$. It should be noted that the chronology of the surroundings of Sremska Mitrovica, Serbia, had $t$-value 3.8 and Glk 69.1, which is just slightly below the significance value.
The similarities among the chronologies could be ascribed to a common positive response to climate, especially June temperatures (Čufar et al., 2008, 2014). Besides the chronologies used in this study, great importance of June temperatures was also identified in Turkey oak (Quercus cerris) on sites in Central Italy (Corona et al., 1995; Romagnoli and Codipietro, 1996) ca. $500 \mathrm{~km}$ away from Kobiljak, which could indicate that even teleconnection with Italian chronologies might be possible.

\subsection{Heteroconnection \\ 3.4. Heterokonekcija}

The results of heteroconnection of the HR1 oak chronology with beech chronologies from 14 locations in Slovenia (Čufar et al. 2008d) showed agreement with 5 beech chronologies (Table 3, Figure 6). The locations of the chronologies are SE of Celje, near Novo

Table 3 Crossdating parameters for comparison of the residual chronology of oak from Kobiljak near Zagreb, Croatia (HR1) with local residual chronologies of beech (Fagus sylvatica) from various sites in Slovenia; for the location, compare Figure 6 (parameters: overlapping - Ovl, coefficient of agreement - Glk\% and t-value $-t_{\mathrm{BP}}$ )

Tablica 3. Parametri za usporedbu rezidualne kronologije hrasta iz Kobiljaka pokraj Zagreba, Hrvatska (HR1) s lokalnim rezidualnim kronologijama bukve (Fagus sylvatica) iz različitih staništa u Sloveniji; lokacije usporediti sa slikom 6. (Ovl preklapanje, Glk - koeficijent slaganja, $\mathrm{t}_{\mathrm{B}}-t$ vrijednost.

\begin{tabular}{|c|c|c|c|c|c|c|c|c|}
\hline \multicolumn{9}{|c|}{ 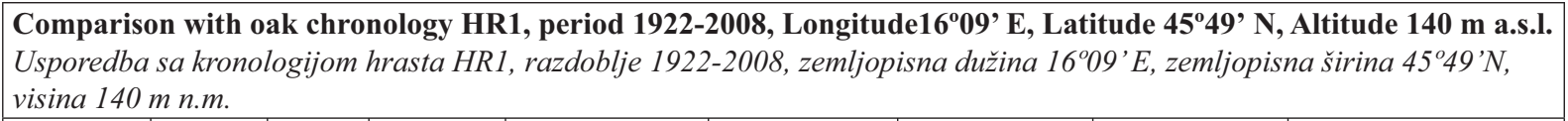 } \\
\hline $\begin{array}{c}\text { Code } \\
\text { Oznaka }\end{array}$ & Ovl & $\mathrm{t}_{\mathrm{BP}}$ & Glk (\%) & $\begin{array}{c}\text { Location } \\
\text { Mjesto }\end{array}$ & $\begin{array}{l}\text { Country } \\
\text { Zemlja }\end{array}$ & $\begin{array}{l}\text { Longitude } \\
\text { Dužina }\end{array}$ & $\begin{array}{l}\text { Latitude } \\
\text { Širina }\end{array}$ & $\begin{array}{l}\text { Altitude (m a.s.l.) } \\
\text { Visina (m n.m.) }\end{array}$ \\
\hline 17 & 78 & 5.8 & 72.1 & Mokronog & Slovenia & $15.20^{\circ}$ & $45.91^{\circ}$ & 400 \\
\hline 5 & 72 & 4.9 & 68.3 & Celje A & Slovenia & $15.54^{\circ}$ & $46.08^{\circ}$ & $300-600$ \\
\hline 6 & 72 & 4.6 & 67.6 & Celje B & Slovenia & $15.37^{\circ}$ & $46.11^{\circ}$ & $300-600$ \\
\hline 2 & 76 & 4.2 & 60.0 & Gorjanci & Slovenia & $15.29^{\circ}$ & $45.76^{\circ}$ & $300-600$ \\
\hline 16 & 78 & 4.0 & 71.4 & Pivka & Slovenia & $14.16^{\circ}$ & $45.80^{\circ}$ & 640 \\
\hline
\end{tabular}




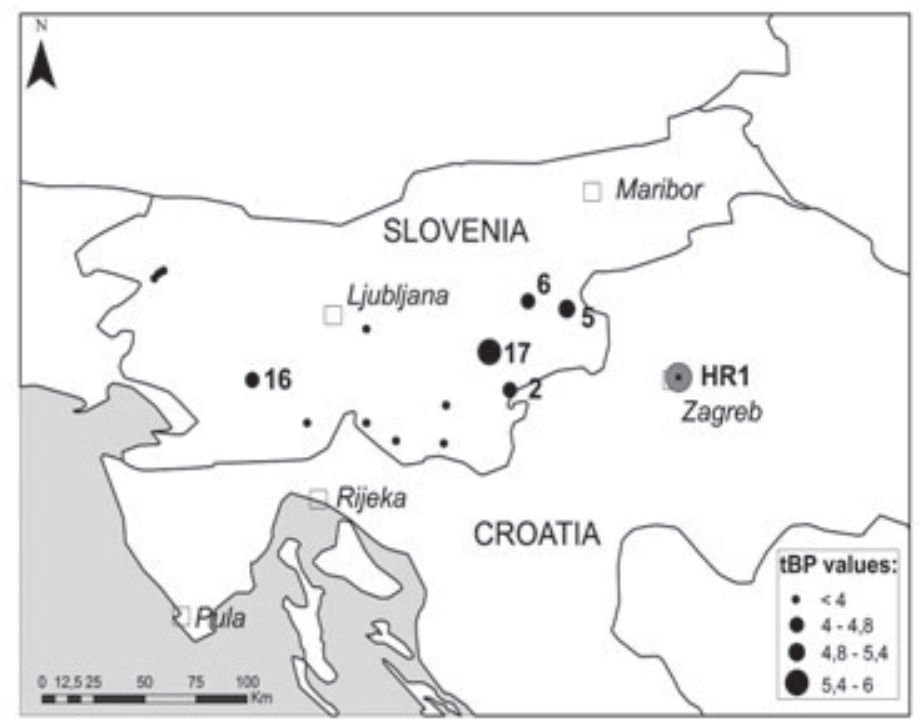

Figure 6 Heteroconnection of oak (Quercus robur) chronology of Kobiljak near Zagreb (HR1) with local beech (Fagus sylvatica) chronologies from Slovenia; the chronologies showing $t_{\mathrm{BP}} \geq 4$ are labelled with numbers, small points without label represent chronologies with $t_{\mathrm{BP}}<4$; for details see Table 3

Slika 6. Heterokonekcija kronologije hrasta (Quercus robur) iz Kobiljaka pokraj Zagreba (HR1) s lokalnim kronologijama bukve (Fagus sylvatica) iz Slovenije; kronologije koje pokazuju $t_{\mathrm{BP}} \geq 4$ naznačene su oznakom i postupno većim točkama, a male točke bez oznake predočuju kronologije $t_{\mathrm{BP}}<4$; statistički su detalji navedeni u tablici 3 .

mesto and near Postojna, at the distance of $60-150 \mathrm{~km}$ from Kobiljak.

\subsection{Potential for improving chronology and different applications}

3.5. Potencijal za usavršavanje kronologije i njezine različite primjene

Croatia has rich wooden cultural heritage, which also includes archaeological wood from the distant past. In the past two decades, the Croatian archaeologists contacted wood scientists from the University of Zagreb and Ljubljana to investigate archaeological wood from their excavations. They pointed out that dendrochronological dating of their artifacts was needed.

The archaeologists Tatjana Tkalčec and Tajana Sekelj Ivančan from the Institute of Archeology in Zagreb requested analyses and dating of wood from three different sites. The first investigations gave no encouraging results. Poor preservation of archaeological wood and low number of tree-rings were the main obstacles for dendrochronological dating (Čufar et al., 2006). However, instructions of wood scientists as to how to properly collect and prepare the material soon led to first successfully dated timbers in the old town of Varaždin (Čufar and Šimek, 2008) and in Torčec gradić (Čufar et al., 2008c). The timbers from Varaždin were dated to 1415 (terminus post quem) and those from Torčec gradić to 1263 (terminus post quem). In both cases, the Slovenian regional oak chronology was used as well as the over 800-year long regional oak chronology of the laboratory of the University of Natural Resources and Applied Life Sciences in Vienna (Wimmer and Grabner, 1998). Since the Austrian and Slovenian regional chronologies crossdate well $\left(t_{\mathrm{BP}}=9.7\right)$ (Čufar et al., 2008a), successful dating of archaeological wood showed that the chronologies from Austria and Slovenia could act as important reference points to de- velop dendrochronology in Croatia. Enhanced co-operation, also including other countries like Hungary, could help to develop a longer regional oak chronology in Croatia and to establish a chronology network in the area south and southeast of the Alps.

\section{CONCLUSION}

\section{ZAKLJUČAK}

The investigated wood from living trees of pedunculate oak in Kobiljak near Zagreb enabled us to build a 127 years long chronology spanning the period 1883-2009. The sufficiently replicated part is 88 years long and spans the period 1922-2009.

Dendroclimatological analysis showed positive effect of June precipitation and negative effect of June temperatures on tree-ring variation. Both signals are stable over time.

Although relatively short, the chronology exhibits good teleconnection, i.e. similarity with other oak chronologies of Austria, Hungary, and Slovenia. The parameters of agreement with the chronology of the surroundings of Sremska Mitrovica, Serbia were just slightly below the significance value.

Surprisingly, the oak chronology of Kobiljak also exhibits good agreement with some beech chronologies from Slovenia, which indicates that it has good potential for heteroconnection, i.e. similarity with chronologies of other species.

Good teleconnection and heteroconnection could be ascribed to a common factor - the climate.

The presented results indicate that the development of dendrochronology in Croatia would help to fill the spatial and chronological gaps to establish a better network of regional oak chronologies in the wider region. 
The presented chronology could be improved and prolonged by including more trees and possibly additional sites and wood from the objects of cultural history. An improved chronology could be used for different purposes including dating objects of cultural heritage. Interest has arisen for this type of use.

\section{Acknowledgements - Zahvale}

The cooperation among international partners was supported by the COST Action FP1106, STREeSS. The work was additionally supported by the Slovenian Research Agency (ARRS), programme P4-0015 and project J6-4087, and Spanish Ministry of Education and Science, project ELENA (CGL2012-31668). We are grateful to Ivan Devčić and Luka Krže for their technical assistance and Edurne Martinez del Castillo for preparing the maps.

\section{REFERENCES}

5. LITERATURA

1. Baillie, M. G. L.; Pilcher, J. R., 1973: A simple crossdating program for tree-ring research. Tree-Ring Bulletin 33:7-14.

2. Baillie, M. G. L., 1995: A slice through time. - B.T. Batsford Ltd., London.

3. Biondi, F., 1997: Evolutionary and moving response functions in dendroclimatology. Dendrochronologia 15: 139-150.

4. Biondi, F.; Waikul, K., 2004: DENDROCLIM2002: A $\mathrm{C}++$ program for statistical calibration of climate signals in tree ring chronologies. Computers \& Geosciences 30: 303-311 http://dx.doi.org/10.1016/j.cageo.2003.11.004.

5. Cook, E. R.; Peters, K., 1997: Calculating unbiased treering indices for the study of climatic and environmental change. Holocene 7(3): 361-370

http://dx.doi.org/10.1177/095968369700700314.

6. Corona, P.; Romagnoli, M.; Torrini L., 1995. Stem annual increments as ecobiological indicators in Turkey oak (Quercus cerris L.). Trees 10(1): 13-19 http://dx.doi.org/10.1007/BF00197774.

7. Čufar, K.; Levanič, T., 1999: Tree-ring investigations in oak and ash from different sites in Slovenia. Phyton (Austria) 39: 113-116.

8. Čufar, K.; Korenčič, T.; Trajković, J., 2006: Drvo s tri arheološka nalazišta u Hrvatskoj i mogućnosti njegova istraživanja [Wood from three archaeological sites in Croatia and its research potential]. Drvna Industrija 57(2): 67-73.

9. Čufar, K., 2007: Dendrochronology and past human activity - A review of advances since 2000 . Tree Ring Research 63(1): 47-60 http://dx.doi.org/10.3959/1536-1098-63.1.47.

10. Čufar, K.; Šimek, M., 2008: Dendrochronological investigation of wood from Varaždin Old Castle [Dendrokronološka istraživanja drva iz Staroga Grada u Varaždinu]. Podravina (Samobor), 7(13): 22-29.

11. Čufar, K.; De Luis, M.; Zupančič, M.; Eckstein, D., 2008a: A 548-year tree-ring chronology of oak (Quercus spp.) for Southeast Slovenia and its significance as a dating tool and climate archive. Tree-Ring Research, 64(1): 3-15 http://dx.doi.org/10.3959/2007-12.1.

12. Čufar, K.; De Luis, M.; Eckstein, D.; Kajfež-Bogataj, L., 2008b: Reconstructing dry and wet summers in SE Slo- venia from oak tree-ring series. International Journal of Biometeorology, 52 (7): 607-615. http://dx.doi.org/10.1007/s00484-008-0153-8.

13. Čufar, K.; Sekelj Ivančič, T.; Grabner, M., 2008c: The dendrochronological dating of wood from the site of Torčec - Gradić in northern Croatia [Dendrokronološko datiranje drva s lokaliteta Torčec - Gradić u sjevernoj Hrvatskoj]. Podravina (Samobor), 7 (13): 30-40.

14. Čufar, K.; De Luis, M.; Berdajs, E.; Prislan, P., 2008d: Main patterns of variability in beech tree-ring chronologies from different sites in Slovenia and their relation to climate [Variabilnost kronologij širin branik bukve z različnih rastišč v Sloveniji glede na klimo]. Zbornik gozarstva in lesarstva, 87: 123-134.

15. Čufar, K.; Zupančič, M.; Krže, L.; De Luis, M.; Eckstein, D., 2010: Dendrochronology of oak (Quercus spp.) in Slovenia: an interim report. In: Levanič, T.; Gričar, J.; Hafner, P.; Krajnc, R.; Jagodić, Š.; Gärtner, H.; Heinrich, I.; Helle, G. (eds). TRACE - Tree Rings in Archaeology, Climatology and Ecology: volume 8: proceedings of the dendrosymposium 2009. April 16th-19th, 2009 in Otočec, Slovenia, (Scientific Technical Report, STR 10/05). Potsdam: GFZ German Research Centre for Geoscience: 132-135.

16. Čufar, K.; Grabner, M.; Morgos, A.; Martinez Del Castillo, E.; Merela, M.; De Luis, M., 2014. Common climatic signals affecting oak tree-ring growth in SE Central Europe, Trees, http://dx.doi.org/10.1007/s00468-013-0972-z.

17. Eckstein, D.; Bauch, J., 1969: Beitrag zur Rationalisierung eines dendrochronologischen Verfahrens und zur Analyse seiner Aussagesicherheit. Forstwissenschaftliches Centralblatt, 88: 230-250. http://dx.doi.org/10.1007/BF02741777.

18. Friedrich, M.; Remmele, S.; Kromer, B.; Hofmann, J.; Spurk, M.; Kaiser, K. F.; Orcel, C.; Küppers, M., 2004: The 12,460-year Hohenheim oak and pine tree-ring chronology from Central Europe - a unique annual record for radiocarbon calibration and paleoenvironment reconstructions. Radiocarbon 46(3): 1111-1122.

http://dx.doi.org/10.1016/1.dendro.2009.03.001.

19. Friedrichs, D.; Trouet, V.; Büntgen U.; Frank D. C.; Esper, J.; Neuwirth; B.; Löffler, J., 2009a: Twentieth century climate sensitivity of Central European tree species. Trees - Structure and Function 23: 729-739. http://dx.doi.org/10.1007/s00468-009-0315-2.

20. Friedrichs, D. A.; Büntgen, U.; Frank, D. C.; Esper, J.; Neuwirth, B.; Löffler, J., 2009b: Complex climate controls on 20th century oak growth in Central-West Germany. Tree Physiology 29: 39-51. http://dx.doi. org/10.1093/treephys/tpn003. Epub 2008 Dec 5.

21. Geihofer, D.; Grabner, M.; Wimmer, R.; Fuchsberger, H., 2005: New master chronologies from historical and archeological timber in Eastern Austria. Proceedings of hte EuroDendro 2005. September $29^{\text {th }}-$ October $1^{\text {st }} 2005$. Viterbo, Italy, 50-51.

22. Grabner, M.; Karanitsch-Ackerl, S.; Holawe, F.; Eissing, T., 2011: Dendroclimatology in a region with heavily used forests - the use of historical wood. In: Cherubini, P., Frank, D., Gärtner, H., Treydte, K., Fonti, P., EuroDendro 2011, 30.

23. Grynaeus, A., 1996: Progress of dendrochronological research in Hungary. Dendrochronologia 14: 223-226.

24. Grynaeus, A., 2003: Dendrochronology and Environmental History, in: József Laszlovszky - Péter Szabó (Eds.), People and Nature. Budapest: 175-193.

25. Guiot, J., 1991: The bootstrapped response function. Tree-Ring Bulletin 51: 39-41. 
26. Haneca, K.; Čufar, K.; Beeckman, H., 2009: Oaks, treerings and wooden cultural heritage: a review of the main characteristics and applications of oak dendrochronology in Europe. Journal of Archaeological Science 36: 1-11. http://dx.doi.org/10.1016/j.jas.2008.07.005.

27. Haneca, K.; Boeren, I.; Van Acker, J.; Beeckman, H., 2006: Dendrochronology in suboptimal conditions: tree rings from medieval oak from Flanders (Belgium) as dating tools and archives of past. Vegetation History and Archaeobotany, 137-144.

http://dx.doi.org/10.1007/s00334-005-0022-x.

28. Haupt, M.; Weigl, M.; Grabner, M.; Boettger, T., 2011: A 400 -year reconstruction of July relative air humidity for the Vienna region (eastern Austria) based on carbon and oxygen stable isotope ratios in tree-ring latewood cellulose of oaks (Quercus petraea Matt. Liebl.) Climatic Change 105(1-2): 243-262. http://dx.doi.org/10.1007/s10584-010-9862-1.

29. Holmes, R. L., 1994: Dendrochronology Program Library User's Manual, Laboratory of Tree-Ring Research. University of Arizona, Tucson, USA.

30. Kelly, P. M.; Leuschner, H.; Briffa, K. R.; Harris, I. C., 2002: The climatic interpretation of pan-European signature years in oak ring-width series. Holocene 12(6): 689694. http://dx.doi.org/10.1191/0959683602hl582rp.

31. Kern, Z.; Grynaeus, A.; Morgós, A.; Horváth, E.; Schmidt, B., 2009a: High and low stands of Balaton Lake (East Central Europe, Hungary): reconstructed endsummer lake levels from AD 1601 based on radial growth of oak trees, EURODENDRO 2009, 26th October to 30th October, 2009, Mallorca, Spain, 104.

32. Kern, Z.; Grynaeus, A.; Morgós, A., 2009b: Reconstructed precipitation for Southern Bakony Mountains (Transdanubia, Hungary) back to AD 1746 based on ring widths of oak trees. Időjárás 113/4: 299-314.

33. Kolár, T.; Kyncl, T.; Rybníček, M., 2012: Oak chronology development in the Czech Republic and its teleconnection on a European scale. Dendrochronologia 30: 243-248.

http://dx.doi.org/10.1016/j.dendro.2012.02.002.
34. Levanič, T.; Čater, M.; McDowell, N., 2011: Associations between growth, wood anatomy, carbon isotope discrimination and mortality in a Quercus robur forest. Tree Physiology 31, 298-308. http://dx.doi.org/10.1093/treephys/tpq111.

35. Morgós, A., 2005: The dating of wood - Dendrochronology and the situation of dendrochronology in Hungary (in Hungarian with abstract subtitles and captions in English). In conference proceedings: Az erdő és a fa régészete és néprajza [Archaeology and Ethnography of Forest and Wood] (editor: János Gömöri), Sopron, Hungary 2007:, 31-88.

36. Pukiene, R.; Ožalas, E., 2007: Medieval oak chronology from the Vilnius Lower Castle. Dendrochronologia, 24(2-3): 137-143

http://dx.doi.org/10.1016/j.dendro.2006.10.007.

37. Romagnoli, M.; Codipietro, G., 1996. Pointer years and growth in Turkey oak (Quercus cerris L) in Latium (central Italy). A dendroclimatic approach. Annales des Sciences Forestières 53(2-3): 671-684 http://dx.doi.org/10.1051/forest:19960245.

38. Szántó, Zs.; Kertész, R.; Morgós, A.; Nagy, D.; Molnár, M.; Grabner, M.; Rinyu, L.; Futó, I., 2007: Combined techniques to date the first Turkish bridge over the Tisza River. Hungary, Radiocarbon, 49(2): 515-526.

39. Wimmer, R.; Grabner, M., 1998: Standardchronologien in Osterreich als Basis fur die dendrochronologische Datierung. Archaeologie Österreichs, 9(2): 79-85.

\section{Corresponding address:}

Professor JELENA TRAJKOVIĆ, Ph.D.

University of Zagreb

Faculty of Forestry

Department for Wood Science

Svetošimunska 25

10000 Zagreb, CROATIA

e-mail: jtrajkovic@sumfak.hr 